\title{
Two novel mutations in ADAMTS13 in a Chinese boy with congenital thrombocytopenic purpura: a case report
}

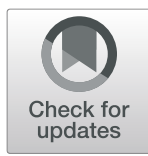

Ling Hou and Yue Du*

\begin{abstract}
Background: Mutations in the ADAMTS13 gene family have been reported to cause congenital thrombotic thrombocytopenic purpura (CTP), a rare disease characterized by thrombocytopenia and hemolytic anemia. Nearly 150 causative mutations in ADAMTS13 have been identified; however, only a few of them were detected in Chinese patients.

Case presentation: A 5-year-old Chinese boy presented with history of thrombocytopenic purpura, hemolytic anemia, and renal injury since the neonatal period. Gene analysis revealed two novel mutations in ADAMTS13: a missense mutation 332G > A (p:Gly111Glu) in exon4 and a nonsense mutation 3121C > T (p:Gln1041stop) in exon 24. Genetic analysis of his parents confirmed the heterozygous nature of the mutations.

Conclusion: We report two novel mutations in ADAMTS13 (332G > A, 3121C > T) in a Chinese boy. These two mutations may lead to early onset of cTTP and severe symptoms.
\end{abstract}

Keywords: Congenital thrombotic thrombocytopenic purpura (CTTP), ADAMTS13, Gene mutation

\section{Background}

Thrombotic thrombocytopenia purpura(TTP) is a rare, life-threatening disease. The condition is caused by the formation of unusually large von Willebrand factor (vWF) multimers (ULVWFMs) owing to the deficiency of vWF cleaving protease (VWF-CP) [1]; this causes abnormal platelet aggregation and results in thrombocytopenic purpura, hemolytic anemia, and microangiopathy in vital organs such as the brain and kidney $[1,2]$. Most cases of TTP have acquired TTP (aTTP) caused by the presence of antibodies or inhibitors of VWF-CP, while cases of congenital TTP (cTTP) caused by gene defect are relatively rare [3]. Levy et al. (2001) reported that the gene that encodes for VWF-CP belongs to the ADAMTS13 family [4]. Since then, more than 80 gene

*Correspondence: 1838907885@qq.com

Pediatric Nephrology Department, Shengjing Hospital of China Medical University, No.36 Sanhao Street Heping District, Shenyang 110004, Liaoning, China

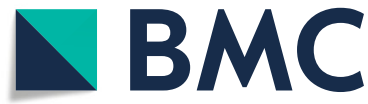

mutations in ADAMTS13 causing cTTP have been reported [5]; most of these were missense mutations, while others were nonsense, insertion, deletion, frameshift, or splicing mutations [6]. However, to the best of our knowledge, only a few Chinese cases of cTTP have been reported with mutations in ADAMTS13 [7-10]. Here we report a Chinese boy with two novel mutations in ADAMTS13: one missense mutation in exon 4 and a nonsense mutation in exon 24. The clinical course was marked by recurrent thrombocytopaenic purpra, haemolytic anaemia, and renal injury since the neonatal period.

\section{Case presentation}

A 5-year-old male Chinese neonate developed jaundice and dark urine at $18 \mathrm{~h}$ after birth. Laboratory investigations revealed hemolytic anemia, thrombocytopenia, and impaired renal function. Hematological examination revealed hemoglobin $(\mathrm{Hb}) 105 \mathrm{~g} / \mathrm{L}$ (normal reference range, $180-190 \mathrm{~g} / \mathrm{L}$ ), platelet count $34 \times 10^{9} / \mathrm{L}$ (normal

(c) The Author(s). 2020 Open Access This article is licensed under a Creative Commons Attribution 4.0 International License, which permits use, sharing, adaptation, distribution and reproduction in any medium or format, as long as you give appropriate credit to the original author(s) and the source, provide a link to the Creative Commons licence, and indicate if changes were made. The images or other third party material in this article are included in the article's Creative Commons licence, unless indicated otherwise in a credit line to the material. If material is not included in the article's Creative Commons licence and your intended use is not permitted by statutory regulation or exceeds the permitted use, you will need to obtain permission directly from the copyright holder. To view a copy of this licence, visit http://creativecommons.org/licenses/by/4.0/. The Creative Commons Public Domain Dedication waiver (http://creativecommons.org/publicdomain/zero/1.0/) applies to the data made available in this article, unless otherwise stated in a credit line to the data. 
reference range, $34 \times 10^{9} / \mathrm{L}$ ), fragmented red blood cells (helmet- or drop-like morphology) in blood smear examination, and negative Coomb's test. The biochemistry parameters were: total bilirubin (TBILI) $479.5 \mu \mathrm{mol} / \mathrm{L}$ (normal reference range, 3.4-20.5 $\mu \mathrm{mol} / \mathrm{L}$ ); unconjugated bilirubin (UCB) $458.8 \mu \mathrm{mol} / \mathrm{L}$ (normal reference range, $3.4-11.9 \mu \mathrm{mol} / \mathrm{L}$ ); lactate dehydrogenase (LDH) $1181 \mathrm{U} / \mathrm{L}$ (normal reference range, 80-285 U/L); serum creatinine $(\mathrm{Scr}) 156.5 \mu \mathrm{mol} / \mathrm{L}$ (normal reference range, 59-104 $\mu \mathrm{mol} / \mathrm{L}$ ), blood urea nitrogen (BUN) 13.89 $\mathrm{mmol} / \mathrm{L}$ (normal reference range, $3-9.2 \mathrm{mmol} / \mathrm{L}$ ). He was diagnosed with hemolytic uremic syndrome (HUS) and achieved remission upon treatment with exchange blood transfusion. At the age of 4 years and 5 months, the boy experienced a relapse with pallor, petechiae, and dizziness; laboratory investigations showed severe thrombocytopenia (platelet count: $8 \times 10^{9} / \mathrm{L}$ ), hemolytic anemia $(\mathrm{Hb} 72 \mathrm{~g} / \mathrm{L}$; schistocytosis on blood smear examination), and impaired renal function (Scr $203.9 \mu \mathrm{mol} / \mathrm{L}$; BUN $13.38 \mathrm{mmol} / \mathrm{L}$ ). His symptoms relieved with plasma exchange; in addition, hypotensive drugs were administered for high blood pressure (as high as 180/100 $\mathrm{mmHg}$ ). Five months later, he experienced second relapse with scattered haemorrhagic dots and platelet count of $16 \times 10^{9} / \mathrm{L}$; his symptoms were relieved with plasma exchange. The most recent relapse happened 4 months later with the symptoms of skin petechiae and dizziness. His platelet count was $18 \times 10^{9} / \mathrm{L}$, glomerular filtration rate (GFR) was $59.14 \mathrm{~mL} / \mathrm{min} / 1.73 \mathrm{~m}^{2}$ (normal reference range, $80-120 \mathrm{~mL} / \mathrm{min} / 1.73 \mathrm{~m}^{2}$ ) and blood pressure was $175 / 107 \mathrm{mmHg}$. Moreover, he developed upper respiratory infection prior to the last two relapses. When the boy was referred to us at the last relapse, ADAMTS13 protein activity, inhibitors were examined by residual-collagen binding assay and ADAMTS 13 gene analysis was performed. ADAMTS13 protein activity was $5.7 \%$ (normal range, 40-130\%), while ADAMTS13 inhibitors were negative; in addition, two novel mutations in this gene were found, which confirmed the diagnosis of cTTP. Subsequently, the boy received prophylactic fresh frozen plasma (FFP) infusion every 2 weeks. He did not develop any relapse in the subsequent 2 months and showed improvement in renal function.

Through polymerase chain reaction (PCR) amplification and direct sequencing of the 29 exons and intron boundaries of the ADAMTS13 gene, two mutations (332G $>\mathrm{A}$ in exon4 and $3121 \mathrm{C}>\mathrm{T}$ in exon 24) were found. The first one $(332 \mathrm{G}>\mathrm{A})$ was a missense mutation involving exchange of glycine for glutamic acid (Gly111Glu), while the other $(3121 \mathrm{C}>\mathrm{T})$ was a nonsense mutation involving exchange of glutamine for a termination codon (Gln1041stop) and a truncated protein that would form in this region. ADAMTS13 gene of the boy's parents were also analyzed, and the results indicated that the boy had inherited $332 \mathrm{G}>\mathrm{A}$ mutation from his mother and $3121 \mathrm{C}>\mathrm{T}$ mutation from his father. This proved that the nature of the mutations that caused cTTP was compound heterozygote mutation (Fig. 1). The parents were carriers of one each of these two novel mutations, and manifested no symptoms of this disease. Nevertheless, the vWF activity had not been detected due to the constraints at our department.

\section{Discussion and conclusions}

Our patient with TTP had been misdiagnosed for a relatively long time. According to Assink et al. (2003) [2], TTP is usually characterized by the pentad of thrombocytopenia, hemolytic anemia, neurologic signs, renal injury, and fever. However, many patients may manifest oligosymptomatic forms, as observed in our patient; our patient had no fever or neurological signs, which made the diagnosis challenging. In 2014, Bendapudi et al. proposed the PLASMIC score to assess the risk of low ADAMTS13 protein activity and suspected TTP; the score is based on symptoms (hemolysis), history (cancer and organ transplant), and laboratory examination (Plt, MCV, Scr, and INR) [11]. According to this score, our patient could be considered as intermediate risk, which might demonstrate its advantages. Moreover, detection of ADAMTS13 inhibitor and ADAMTS13 sequences may help confirm the diagnosis of TTP.

HUS and TTP have similar characteristics such as thrombocytopenia, nonimmune haemolytic anaemia, and multiorgan dysfunction; however, the two conditions are believed to be different disease entities [12]. Our patient showed signs of mild-moderate renal injury; this is in contrast to the patient reported by Schneppenheim [13], who developed acute renal failure. Other differentiating points from HUS include the lack of increase in fibrinogen levels and the absence of gastrointestinal symptoms throughout the disease course [1]. In addition, the level of ADAMTS13 protein activity and inhibitors are obviously lower in cTTP, as seen in our patient; this is different from HUS.

ADAMTS13 is approximately $37 \mathrm{~kb}$ long and is located at chromosome 9q34. From its $\mathrm{N}$ terminus the encoded metalloprotease ADAMTS13 comprises a signal peptide domain, a propeptide domain, a metalloprotease domain, a disintegrin like domain, a thrombombospondin type 1 repeat (TSP1) domain, a cysteine-rich domain, a spacer domain, seven additional TSP1 repeats, and two terminal complement $\mathrm{C} 1 \mathrm{r} / \mathrm{C} 1 \mathrm{~s}$, Uegf, Bmp1 (CUB) domains [13]. Till date, mutations in ADAMTS13 that cause cTTP have been found to affect nearly all these domains [14]. The missense mutation of $332 \mathrm{G}>\mathrm{A}$ in exon 4 is in the metalloprotease region, which correlates with the protease activity of ADAMTS13. More than 19 mutations 

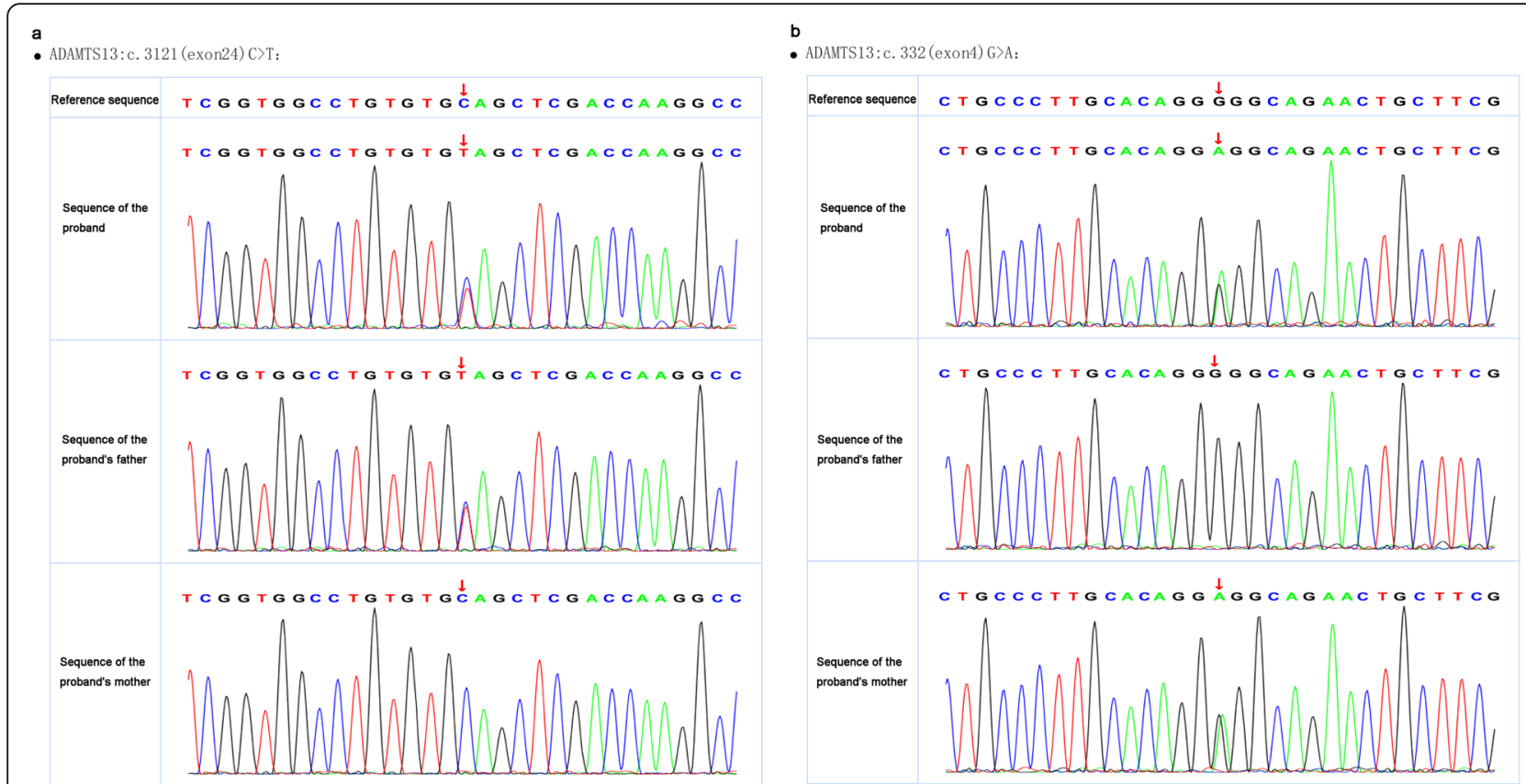

Fig. 1 a $332 \mathrm{C}>\mathrm{A}$ in exon4. b $3121 \mathrm{C}>\mathrm{T}$ in exon24

have been found in this region; according to vivo and vitro studies, these may affect the ADAMTS13 function by reducing the secretion of or the cleavage activity of protease $[15,16]$. According to a previous case report, the proximity of exon 4 to calcium binding sites in aa82 and aa173 may explain the consequences of the mutation; the Gly111Glu caused by $332 \mathrm{G}>\mathrm{A}$ in our patient is also located in close proximity to these two sites in this region [17]. The other mutation was a nonsense mutation in the TSP1-7 region; the effects of mutations in this region have not been clearly reported (Fig. 2). Kazuyoshi et al. [18] found a species of naturally variant mouse with ADAMTS13 lacking TSP1-7, 8 and two CUB domains;in vitro, these truncated recombinant ADAMTS13 also showed VWF-CP activity. Nevertheless, the reported cases with mutations, especially nonsense mutations in TSP1-7, 8 domains in ADAMTS13, often manifested severe clinical symptoms [1, 4, 19-21]. Besides, in their in vivo and vitro studies, both Donadelli and Camilleri found that mutations in the TSP1-7 domains of ADAMTS13 may affect the catalytic activity or secretion of VWF-CP [22, 23].

Our patient showed early onset of symptoms such as jaundice, thrombocytopenia, and anaemia. However,

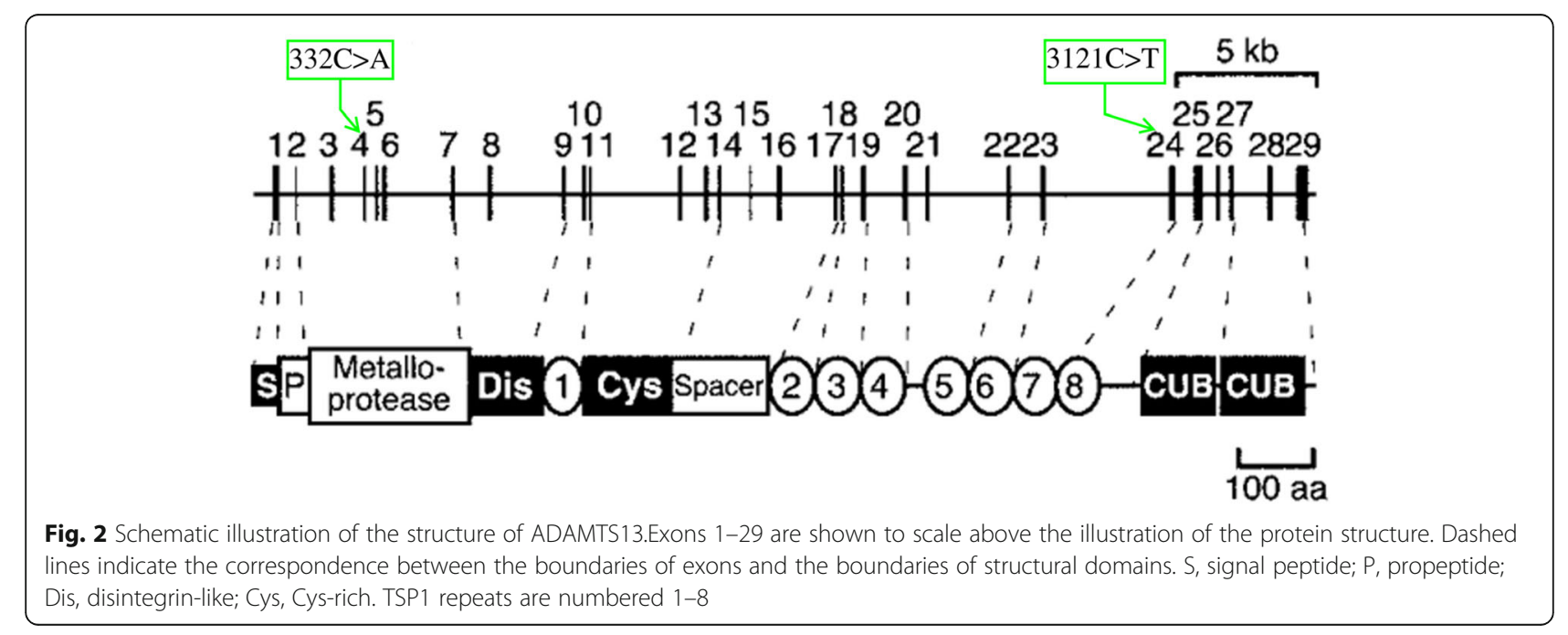


there are several case reports where in the patient suffered the first episode during adolescence, adulthood, or even in old age; moreover, the disease severity also showed considerable variability [24-26]. The heterogeneity in phenotype is not clearly explained by the difference in genotype. A patient with a homozygous mutation in exon4 was reported by Meyer et al. [17];they suggested that mutations in the metalloprotease domain may lead to a first TTP bout in young adulthood, rather than in early childhood. Therefore, in comparison to previous reports, the neonatal onset in our case may be attributable to the nonsense mutation in TSP1-7 [2427];however, the phenotype-genotype correlation of ADAMTS13 has not been established partly because of the rarity of homozygous cases [5, 20, 28-32].

We reported a Chinese boy with cTTP who presented with recurrent thrombocytopenia, haemolytic anaemia, and renal injury. Two novel mutations, a missense mutation $332 \mathrm{G}>\mathrm{A}$ in exon4 and a nonsense mutation $3121 \mathrm{C}>\mathrm{T}$ in exon 24 , were detected in this patient. The nonsense mutation of $3121 \mathrm{C}>\mathrm{T}$ may have contributed to the early disease onset in the neonatal period.

\section{Abbreviations}

CTTP: Congenital thrombotic thrombocytopenic purpura; TTP: Thrombotic thrombocytopenia purpura; vWF: von Willebrand factor; ULWWFMs: Unusually large von Willebrand factor (VWF) multimers; WWF-CP: vWF cleaving protease; aTTP: acquired TTP; cTTP: congenital TTP; Hb: Hemoglobin; TBILI: Total bilirubin; UCB: Unconjugated bilirubin; LDH: Lactate dehydrogenase; Scr: Serum creatinine; BUN: Blood urea nitrogen; HUS: Hemolytic uremic syndrome; GFR: Glomerular filtration rate; FFP: Fresh frozen plasma; PCR: Polymerase chain reaction; TSP1: Thrombombospondin type 1 repeat; CUB: C1r/C1s, Uegf, Bmp1

\section{Acknowledgements}

Not applicable.

\section{Authors' contributions}

LH collected data and reviewed the literature and contributed to manuscript drafting; YD was responsible for the revision of the manuscript. All authors read and approved the final manuscript.

\section{Funding}

None.

\section{Availability of data and materials}

The gene sequencing data of ADAMST13 is stored in NCBI Sequence Read Archive (SRA) (accession number: SRR11248993).

\section{Ethics approval and consent to participate}

This study was approved by the ethics committee of Shengjing Hospital of China Medical University (2018PS497K). All procedures performed in studies involving human participants were in accordance with the ethical standards of the institutional and/or national research committee and with the 1964 Helsinki declaration and its later amendments or comparable ethical standards. Written informed consent was obtained from the patient's parent/ guardian included in the study.

\section{Consent for publication}

Written informed consent was obtained from the patient's parent/guardian for publication of this Case report and any accompanying images. A copy of the written consent is available for review by the Editor of this journal.

\section{Competing interests}

The authors declare that they have no competing interests.

Received: 18 October 2019 Accepted: 10 March 2020

Published online: 20 March 2020

\section{References}

1. Schneppenheim R, Budde U, Oyen F, Angerhaus D, Aumann V, Drewke E, et al. von Willebrand factor cleaving protease and ADAMTS13 mutations in childhood TTP. Blood. 2003;101:1845-50.

2. Assink K, Schiphorst R, Allford S, Karpman D, Etzioni A, Brichard B, et al. Mutation analysis and clinical implications of von Willebrand factor-cleaving protease deficiency. Kidney Int. 2003;63:1995-9.

3. Kokame K, Aoyama Y, Matsumoto M, Fujimura Y, Miyata T. Inherited and de novo mutations of ADAMTS13 in a patient with Upshaw-Schulman syndrome. J Thromb Haemost. 2008;6:213-5.

4. Levy GG, Nichols WC, Lian EC, Foroud T, McClintick JN, McGee BM, et al. Mutations in a member of the ADAMTS gene family cause thrombotic thrombocytopenic purpura. Nature. 2001;413:488-94.

5. Camilleri RS, Scully M, Thomas M, Mackie IJ, Liesner R, Chen WJ, et al. A phenotype-genotype correlation of ADAMTS13 mutations in congenital thrombotic thrombocytopenic purpura patients treated in the United Kingdom. J Thromb Haemost. 2012;10:1792-801.

6. Yadav S, Shetty S, Kulkarni B. A novel homozygous frameshift mutation in exon 7 of the ADAMTS13 gene in a patient with congenital thrombotic thrombocytopenic purpura from India: a case report. Transfusion. 2017;57: 2712-4.

7. Prestidge TD, Rurali E, Wadsworth L, Wu JK, Moore JC, Bresin E. Congenital thrombotic thrombocytopenic purpura (CTTP) with two novel mutations. Pediatr Blood Cancer. 2012:59:1296-8.

8. Conboy E, Partain PI, Warad D, Kluge ML, Arndt C, Chen D, et al. A severe case of congenital thrombotic thrombocytopenia Purpura resulting from compound Heterozygosity involving a novel ADAMTS13 pathogenic variant. J Pediatr Hematol Oncol. 2018;40:60-2.

9. Fu LL, Ma J, Ma JY, Zhang R, Gu H, Chen ZP, et al. Analysis of 5 children with congenital thrombotic thrombocytopenic purpura. Zhonghua Er Ke Za Zhi. 2019:57:50-4.

10. Liu F, Jin J, Dong NZ, Wang YG, Ruan CG. Identification of two novel mutations in ADAMTS13 gene in a patient with hereditary thrombotic thrombocytopenic purpura. Zhonghua Xue Ye Xue Za Zhi. 2005;26:521-4.

11. Bendapudi PK, Li A, Hamdan A. Derivation and prospective validation of a predictive score for the rapid diagnosis of thrombotic thrombocytopenic purpura: the plasmic score. Blood. 2014;124:231.

12. Licht C, Stapenhorst L, Simon T, Budde U, Schneppenheim R, Hoppe B. Two novel ADAMTS13 gene mutations in thrombotic thrombocytopenic purpura/hemolytic-uremic syndrome (TTP/HUS). Kidney Int. 2004;66:955-8.

13. Zheng X, Chung D, Takayama TK, Majerus EM, Sadler JE, Fujikawa K. Structure of von Willebrand factor-cleaving protease (ADAMTS13), a metalloprotease involved in thrombotic thrombocytopenic purpura. J Biol Chem. 2001;276:41059-63.

14. Lotta LA, Garagiola I, Palla R, Cairo A, Peyvandi F. ADAMTS13 mutations and polymorphisms in congenital thrombotic thrombocytopenic purpura. Hum Mutat. 2010;31:11-9.

15. Hommais A, Rayes J, Houllier A, Obert B, Legendre P, Veyradier A, et al. Molecular characterization of four ADAMTS13 mutations responsible for congenital thrombotic thrombocytopenic purpura (Upshaw-Schulman syndrome). Thromb Haemost. 2007;98:593-9.

16. Underwood M, Peyvandi F, Garagiola I, Machin S, Mackie I. Degradation of two novel congenital TTP ADAMTS13 mutants by the cell proteasome prevents ADAMTS13 secretion. Thromb Res. 2016;147:16-23.

17. Meyer SC, Jeddi R, Meddeb B, Gouider E, Lammle B, Kremer Hovinga JA. A first case of congenital TTP on the African continent due to a new homozygous mutation in the catalytic domain of ADAMTS13. Ann Hematol. 2008;87:663-6.

18. Banno F, Kaminaka K, Soejima K, Kokame K, Miyata T. Identification of strainspecific variants of mouse Adamts13 gene encoding von Willebrand factorcleaving protease. J Biol Chem. 2004;279:30896-903.

19. Veyradier A, Lavergne JM, Ribba AS, Obert B, Loirat C, Meyer D, et al. Ten candidate ADAMTS13 mutations in six French families with congenital thrombotic thrombocytopenic purpura (Upshaw-Schulman syndrome). J Thromb Haemost. 2004;2:424-9. 
20. Rossio R, Ferrari B, Cairo A, Mancini I, Pisapia G, Palazzo G, et al. Two novel heterozygote missense mutations of the ADAMTS13 gene in a child with recurrent thrombotic thrombocytopenic purpura. Blood Transfus. 2013;11: 241-4.

21. Matsumoto M, Kokame K, Soejima K, Miura M, Hayashi S, Fujii Y, et al. Molecular characterization of ADAMTS13 gene mutations in Japanese patients with Upshaw-Schulman syndrome. Blood. 2004;103:1305-10.

22. Camilleri RS, Cohen H, Mackie IJ, Scully M, Starke RD, Crawley JT, et al. Prevalence of the ADAMTS-13 missense mutation R1060W in late onset adult thrombotic thrombocytopenic purpura. J Thromb Haemost. 2008;6: $331-8$.

23. Donadelli R, Banterla F, Galbusera M, Capoferri C, Bucchioni S, Gastoldi S, et al. In-vitro and in-vivo consequences of mutations in the von Willebrand factor cleaving protease ADAMTS13 in thrombotic thrombocytopenic purpura. Thromb Haemost. 2006:96:454-64.

24. Tao Z, Anthony K, Peng Y, Choi H, Nolasco L, Rice L, et al. Novel ADAMTS13 mutations in an adult with delayed onset thrombotic thrombocytopenic purpura. J Thromb Haemost. 2006;4:1931-5.

25. Krabbe JG, Kemna EW, Strunk AL, Jobse PA, Kramer PA, Dikkeschei LD, et al. Adult-onset congenital thrombotic thrombocytopenic purpura caused by a novel compound heterozygous mutation of the ADAMTS13 gene. Int J Hematol. 2015:102:477-81.

26. Epperla N, Hemauer K, Friedman KD, George JN, Foy P. Congenital thrombotic thrombocytopenic purpura related to a novel mutation in ADAMTS13 gene and management during pregnancy. Am J Hematol. 2016; 91:644-6.

27. Bestetti G, Stellari A, Lattuada A, Corbellino M, Parravicini C, Calzarossa C, et al. ADAMTS 13 genotype and VWF protease activity in an Italian family with TTP. Thromb Haemost. 2003;90:955-6.

28. Savasan S, Lee SK, Ginsburg D, Tsai HM. ADAMTS13 gene mutation in congenital thrombotic thrombocytopenic purpura with previously reported normal WWF cleaving protease activity. Blood. 2003;101:4449-51.

29. Shibagaki Y, Matsumoto M, Kokame K, Ohba S, Miyata T, Fujimura Y, et al. Novel compound heterozygote mutations (H234Q/R1206X) of the ADAMTS13 gene in an adult patient with Upshaw-Schulman syndrome showing predominant episodes of repeated acute renal failure. Nephrol Dial Transplant. 2006:21:1289-92.

30. Snider CE, Moore JC, Warkentin TE, Finch CN, Hayward CP, Kelton JG. Dissociation between the level of von Willebrand factor-cleaving protease activity and disease in a patient with congenital thrombotic thrombocytopenic purpura. Am J Hematol. 2004;77:387-90.

31. Pimanda JE, Maekawa A, Wind T, Paxton J, Chesterman CN, Hogg PJ. Congenital thrombotic thrombocytopenic purpura in association with a mutation in the second CUB domain of ADAMTS13. Blood. 2004;103:627-9.

32. Metin A, Unal S, Gumruk F, Palla R, Cairo A, Underwood M, et al. Congenital thrombotic thrombocytopenic purpura with novel mutations in three unrelated Turkish children. Pediatr Blood Cancer. 2014;61:558-61.

\section{Publisher's Note}

Springer Nature remains neutral with regard to jurisdictional claims in published maps and institutional affiliations.

Ready to submit your research? Choose BMC and benefit from:

- fast, convenient online submission

- thorough peer review by experienced researchers in your field

- rapid publication on acceptance

- support for research data, including large and complex data types

- gold Open Access which fosters wider collaboration and increased citations

- maximum visibility for your research: over $100 \mathrm{M}$ website views per year

At BMC, research is always in progress.

Learn more biomedcentral.com/submissions 